Canadian University Music Review

Revue de musique des universités canadiennes

\title{
Efforts to Astonish
}

\section{Tom Gordon}

Volume 22, numéro 1, 2001

Jean Cocteau: Evangelist of the Avant-garde

Jean Cocteau : évangéliste de l'avant-garde

URI : https://id.erudit.org/iderudit/1014496ar

DOI : https://doi.org/10.7202/1014496ar

Aller au sommaire du numéro

\section{Éditeur(s)}

Canadian University Music Society / Société de musique des universités canadiennes

ISSN

0710-0353 (imprimé)

2291-2436 (numérique)

Découvrir la revue

Citer cet article

Gordon, T. (2001). Efforts to Astonish. Canadian University Music Review / Revue de musique des universités canadiennes, 22(1), 3-21.

https://doi.org/10.7202/1014496ar
Résumé de l'article

Cocteau était convaincu que son épiphanie dans l'avant-garde datait du choc produit par l'œuvre révolutionnaire de Stravinsky, Le Sacre du printemps. En 1913, Diaghilev avait enjoint Cocteau de le surprendre par cette formule célèbre : « Étonne-moi! » Parmi les efforts que Cocteau a fournis dans le dessein d'étonner, le plus excitant est sa collaboration projetée avec Stravinsky en 1914, le ballet David, une œuvre que l'on avait d'abord jugée sans conséquence. Même auparavant, Cocteau avait commencé une « mue » qu'il a plus tard définie comme sa vraie naissance en tant qu'artiste. Le Potomak, qualifié de roman par son auteur, est en partie une fable imagée, un flot d'idées somnambuliques, un condensé d'aphorismes incendiaires ou, selon Cocteau lui-même, une " courbe de température " - une rêverie par émulation envers le compositeur du Sacre. Cet essai évalue Le Potomak par la narration de l'« étonnement " de Cocteau en tant qu'indice de compréhension de l'avant-garde musicale en France pendant les premières décennies du XX siècle.
All Rights Reserved (C) Canadian University Music Society / Société de musique des universités canadiennes, 2002
Ce document est protégé par la loi sur le droit d'auteur. L'utilisation des services d'Érudit (y compris la reproduction) est assujettie à sa politique d'utilisation que vous pouvez consulter en ligne.

https://apropos.erudit.org/fr/usagers/politique-dutilisation/ 


\section{EFFORTS TO ASTONISH}

\section{Tom Gordon}

Within that bounty of epiphanies which Cocteau claims to have visited his artistic evolution, one-the first-stands out as being the most genuinely cathartic. Following fast on the heals of Diaghilev's famous injunction "Étonne-moi!," Cocteau's witness to a "modern martyrdom" in the Théâtre des Champs-Élysées on the evening of 29 May 1913 did indeed cause an awakening-or as he chose to interpret it, a falling asleep to false reality-that would set the creative course for most of the rest of his life. Throughout the next decade - a decade of monumental significance in Cocteau's assumption of the role of an evangelist in the French avant-garde-Cocteau repeatedly returned to the evening of the premiere of Stravinsky's Le Sacre du printemps. His vivid evocation of the riot which took place in the theatre-replete with a disheveled and scarlet-faced dowager Countesses shrieking from the loge-has become an important chapter in the mythology of Stravinsky's epochal ballet. But Cocteau's self-implication in the aftermath of the event was also an exercise in myth-building. His various accounts of that night imply an intimacy with the inner circle of the Ballets russes which he did not, in fact, enjoy. ${ }^{1}$ It was a thinly veiled campaign to be deemed avant-garde by association. Beset by the need to shock, Cocteau was covetous of the lesson in being shocking which he read in Le Sacre du printemps. Over the next decade he would indeed achieve the status of astonisher through his own efforts and through his collaborations with musicians, artists and writers representing the pantheon of war-time and post-war "isms" in France. But on that evening in May of 1913 Cocteau's future adventures with Picasso, with Radiguet, with the tumultuous circus of Les Six were not yet foreseeable. Cocteau knew only that he had been witness to a martyrdom which he knew he did not fully comprehend. In his guise as first-person narrator of Le Potomak he admitted to Argémone:

One night at the theatre a new masterwork was performed. People hissed, laughed, caterwauled, barked. Oh, how I envied that martyrdom! I envied, I

1 Robert Craft, the veracity of whose truth serums is sometimes also open to question, has definitively refuted Cocteau's authority in the matter of the opening night ablutions, stating that it would be impossible for him to have been present at the legendary ride through the Bois de Boulogne. Francis Steegmuller, whose objectivity is more credible, compares three different versions of Cocteau's own accounts of the Sacre premiere and its aftermath. Using direct and corroborative evidence, Steegmuller makes clear that Cocteau's famous account of the aftermath of Le Sacre is greatly embellished. Francis Steegmuller, Cocteau, A Biography (London: Constable, 1970), 88-90. 
feared that martyrdom. I was ashamed, feeling unworthy of it. I awaited grace as though it were the egg of an archangel. ${ }^{2}$

The anecdotal significance of the premiere of Le Sacre du printemps in Cocteau's artistic evolution is an essential element of the Cocteau canon. Every biographer devotes a chapter to it; ${ }^{3}$ and several of the participants in the event have made a point of refuting its mythologizing tendencies. But beyond the fact that Le Sacre occurred and Cocteau witnessed it, how precisely did Stravinsky's remarkable ballet give shape to Cocteau's artistic awakening and subsequent transformation? What was it about Le Sacre that catapulted Cocteau from one bank of the Seine to the other? Or more precisely, how is Cocteau's admittedly imperfect understanding of Le Sacre du printemps reflected in his transformation from poète frivole of the fashionable salons to a "take-nohostages" avant-gardiste in the creative anarchy of post-war Paris?

Set against the imperative to astonish, the answers to these questions about Cocteau's understanding of Le Sacre du printemps and its lessons are revealed in the works and projects he undertook in the immediate wake of his epiphany of May 1913. In the twelve months which followed the premiere of Le Sacre, Cocteau produced the first major work which he would admit to his ouvres complètes. Begun as an "unplayable modern tragedy" Le Potomak finally hit print as a surreal amalgam: part novel, part graphic fable, interlaced with a series of half-sleeping confessions and a compendium of aphorisms which anticipate Le Coq et l'Arlequin of five years later. Although Cocteau's continuing references to the impact of Le Sacre rather than to the nature of the work, suggest that his deepest impressions were of the effect the work had on its public-i.e., its ability to astonish-evidences of the nature of Le Sacre and of Stravinsky's own creative process do emerge in a reading of Le Potomak. The sycophantic dedications (yes, there were more than one!) to Stravinsky confirm that Cocteau composed Le Potomak under the hallucinatory spell of Sacre's succès de scandale.

But before the ink was dry-and well before Potomak's war-postponed publication in 1919-Cocteau realized that imitation, even in the form of a quite original transposition of medium, was not a passport to the avant-garde. If he were to succeed in astonishing, he would have to do it in the company of those who were already there and it was toward this end that he proposed one of the most elusive and tantalizing failed projects of the twentieth century, David. A pocket-ballet with scenario by Cocteau and score by Stravinsky, David was slated for production by Jacques Copeau's théâtre du Vieux-Colombier. Some-

2"Un soir, au théâtre, on jouait un nouveau chef-d'œuvre. On sifflait, on riait, on miaulait, on aboyait. Ah! Que j'enviai ce martyre! J'enviai, je redoutai ce martyre. J'eus honte de me sentir indigne. En moi la grâce attendait comme un œuf d'archange." Jean Cocteau, Le Potomak, 1913-1914, précédé d'un Prospectus 1916, in Euvres complètes, vol. 11 (Genève: Marguerat, 1947), 260.

3 Bettina Liebowitz Knapp, in Jean Cocteau (New York: Twayne Publishers, 1970), opens "Scandal ... Scandal ..."-the second chapter of her Cocteau biography-with the anecdote. Monique Lange offers up the same image as the opening of chapter 13, "Diaghilev comme toujours capable de gentillesse et de crime" in her study Cocteau, Prince sans royaume (Paris: J. C. Lattès, 1989). The story also appears as the pivotal anecdote in "A Kind of Fireworks," the third chapter of Steegmuller's monograph. 
time between the negotiations of the commission in January- February 1914 and the early summer of the same year, the project was abandoned. Late in life Stravinsky claimed that he never did understand what Cocteau had in mind with David and that the young and ambitious litterateur made a nuisance of himself with the project. While the latter part of the statement may be true, the former is probably not. Correspondence at the Stravinsky Archives in Basel, together with Cocteau's published correspondence demonstrates that the David project was well advanced and developed before it was abandoned. Further, it confirms that Stravinsky himself had a significant hand in defining the nature of the work. Long regarded as little more than a footnote in any study of Stravinsky's path to neo-classicism, this ballet project had fallen victim to Ballets russes chicanery and literary back-biting in pre-war Paris. Despite published references to the existence of both developed scenario and some music, David has been little explored. Yet the scenario, musical sketches and a bounty of correspondence surrounding the project reveal that, although the work was never completed, it constituted a coming of age in Cocteau's understanding of the true nature of the avant-garde and a foundation for most of the remarkable work he produced within and around the sphere of musicians in the war years and through the 1920s.

\section{AN IMPERATIVE TO ASTONISH}

By 1907 Cocteau had been adopted as a darling of the salons of "le tout Paris." A witty flatterer and dazzling monologuist, he apprenticed himself to the poets and matinee idols of the Right Bank until he had honed their styles into a facile and well-blended composite. He produced three volumes of unremarkable drawing-room poetry. The title of one of them, Le Prince frivole, was to shadow him throughout his life as an apt epithet for the poet himself. When the Ballets russes stormed Paris with its vogue-setting exoticism, Cocteau was among the first to surrender. But whereas "le tout Paris" was content to succumb from the loges, Cocteau coveted the seductions behind-the-scenes. As he had before in the salons, Cocteau became a sort of acolyte at Diaghilev's altar, ready to put his connections and his flair for publicity at the impresario's disposal. By 1912 Cocteau was staking a claim for immortality on the scenario of a ballet called Le Dieu bleu. With a score by his salon-frère Reynaldo Hahn, the work was a kind of reductio ad absurdum of all the trappings of fashionable orientalia: star-crossed lovers in a jungle temple setting, wicked priests and a deux ex machina in the form of Nijinsky painted a luminous blue. It had a very brief run. It was during the season of Le Dieu bleu, that Diahgilev uttered the two word challenge which Cocteau has claimed altered his life: "Étonne-moi!" Cocteau, who seemed born with a "bon mot" in his mouth, would never have given thought to astonishing anyone. Yet Diaghilev's command rattled the very foundations of his bourgeois soul.

And yet it was clear that at this same time Diaghilev was not the only of Cocteau's monsters on whom he was failing to register with sufficient impact. During the summer of 1912 Cocteau's fledgling correspondence with André Gide records several attempts to encourage Gide to bring Cocteau's third 
volume of poetry La Danse de Sophocle to the attention of La Nouvelle Revue française. When that attention finally arrived in September, it came in the form of a condemnatory review by one of the NRF's six founders, Henri Ghéon. ${ }^{4}$ Acknowledging Cocteau as a writer of great talent, Ghéon found those talents to be squandered in Cocteau's latest volume of poetry which he pronounced hack work of a salon poet. These brusque rebuffs emanating from the very centre of the milieux in which Cocteau was desperately seeking entry, clearly alerted Cocteau to the necessity of a shift in what he was doing. But how to achieve that shift-how to astonish - was a matter which eluded him until he witnessed the colossal mass astonishment evoked by Le Sacre's premiere.

\section{Potomak}

Just a few short months after that premiere, Cocteau found himself at JacquesÉmile Blanche's estate where he had gone to write an "unplayable modern tragedy" (Le Sacre d'un bourgeois?), but found himself drawing cartoons and elaborating fantasies for Blanche's nephew instead. Cocteau described the genesis of Le Potomak as a case of automatic drawing. First the monstrous Eugènes surged from his pen. They took on a life of their own in graphic form and then in the accompanying text. To these he added "a great number of scattered notes" which he had been accumulating and gathered the whole into a book which he completed in March 1914 during his visit to Stravinsky in Switzerland. The work was consigned to a war-time limbo where it would await publication in 1919. In 1916 Cocteau added a "Prospectus" which, like some of the book proper, anticipated the aphoristic pronouncements of Le Coq et l'Arlequin.

Le Potomak defies easy synopsis. In parallel and sometimes intersecting forms the surreal graphic parable of the monstrous Eugènes and the moribund Mortimers whom they stalk, ingest and regurgitate offers a counterpoint to the narrated visits of the first-person speaker to the subterranean world of the Potomak himself, a large, multi-phallic jellyfish who lives underneath the Place de la Madeleine and exists on a diet of olive oil, gloves, spelling mistakes and Ballets russes programs. All characters are doubles, through some surreal filter, of individuals in Cocteau's life. The most frequent appearances are made by Cocteau himself as narrator to this surreal picaresque. But Cocteau assumes other skins as well, alter-egoing between the thoroughly astonishing Eugènes (named after himself, his mother and his maternal grandfather) and his bourgeois past in the MORT-imers. Cocteau's personal appetites are shared with Potomak himself.

The volume is framed by two versified dedications to Stravinsky, one more dauntingly obsequious than the other. In the three-page prefatory dedication to Stravinsky he stated, "This is not a book, but rather a fever chart." 5 The illness? Surely it was that envy induced by Le Sacre. At the book's close Cocteau appended a five-page verse, headed “À Igor Stravinsky, Leysin, Mars.-1914."

4Henri Gheon, "Les poèmes," La Nouvelle Revue française VIII (September 1912): 507-11.

5 "Il n'y a pas eu de livre; tout au plus une feuille de température." Cocteau, Le Potomak (Prospectus 1916), 45. 
It was profusely evocative of Cocteau's visit to Stravinsky in Switzerland where they worked together on David. Cocteau identified his completion of Potomak with Stravinsky's completion of Rossignol and suggested a creative camaraderie. He confirmed that Stravinsky is the character Canche in the narrative (who speaks some unmistakable Stravinskysms) and credited the composer's role in his own rebirth.

Igor, I planned to offer you a book and I offer you my old skin.

From the shadow, from my old skin, from the clouds

(behind which the Alps appeared undoubtedly a little terrible).

Some lame paragraphs.

Some foolish paragraphs.

Some contradictory paragraphs.

But, from time to time, a phrase-like the doves which Robert Houdin

captures anywhere. An incandescence which freezes ... a vagueness which congeals ... a grasp at the unknown. My book is to me the Ecce Deus, the perpetual drought, and the manna which rains.

-Canche, you are so full, Oh! How empty I feel! ${ }^{6}$

Cocteau's fever chart itself stands as a testament to the nature of his own understanding of Stravinsky's ballet. Later, in one installment of his selfincluding mythologies around Le Sacre, Cocteau would identify the ballet as an extension of fauvism: "an organized fauvist work" but somewhat behind its time. ${ }^{7}$ Certainly the assorted monsters who populate Cocteau's drawings and narrative reflected the terrifying fauvism he saw in Sacre. Cocteau claimed that his strange caricatures literally "surged up from the score of Le Sacre". 8 The bizarre and carnivorous Eugènes who travel in packs and devour unsuspecting bourgeois tourists, or Potomak himself whose grisly fortitude is typified by his being able to endure two days of incessant Wagner played by an American music box. From Cocteau's post-Sacre vantage point, it's hard to know which is more terrifying, the eminently bourgeois Mortimers in their Tyrolean hats, placidly consuming culture or the ferocious Eugènes with their greedy appetites and penchant for simultaneity. But however "fauvist" the anecdote of Le Sacre's scenario, it was hardly sufficient to explain the ballet's

6"Igor, je comptais t'offrir un livre et je t'offre ma vieille peau.

De la pénombre, de la vieille peau, des nuages (derrière lesquels, sans doute un peu, l'Alpe terrible apparaît).

Des paragraphes boiteux.

Des paragraphes bêtes.

Des paragraphes contradictoires.

Mais, de temps en temps, une phrase, pareille à ces colombes que Robert Houdin attrape n'importe où Une incandescence qui se gèle ... une nébuleuse qui se coagule ... un rapt à l'inconnu. Mon livre à moi, c'est de l'Ecce Deus, de la disette qui s'éternise et de la manne qui pleut.

-Canche, vous êtes plein. Ô! que je me sens vide!" Ibid., 340-41.

7 Jean Cocteau, Cocteau's World: An Anthology of Writings by Jean Cocteau, trans, ed. and intr. by Margaret Crosland (London: Peter Owen, 1972), 322. Originally in "Le Sacre du printemps," as published in Cocteau, Euvres complètes, vol. $9,48$.

8 Cited in Steegmuller, Cocteau, A Biography, 90. 
astonishing reception. And imagery alone is far from Le Potomak's sole novelty.

A far more significant connection lay in the message of contradiction which Le Potomak actively preaches. Epigrams like "Cultivate whatever the public reproaches you for: it is you" or "Beware of those who preserve old anarchies!"9 were laced throughout the non-sequential text. Cocteau began to fashion a doctrine which belongs to every revolution in the arts. It would grow into a modus operandi of the "Nouveaux Jeunes" of the twenties. The shellshock experience of Le Sacre taught him that unless art insulted the habits of art (which for Cocteau were the bourgeois habits cultivated by a salon life), it would remain a mere game. And whereas his sources are carefully veiled throughout of the rest of Le Potomak, his source for the spirit of contradiction is trumpeted in the "Prospectus" which precedes the volume.

At the age of nineteen I was celebrated by some for my foolishness ... I became absurd, a waster, a gossip, taking my gossip and my squander for eloquence and prodigiousness. Then came the Russian Extravaganzas. - These incomparable celebrations were capable of completely disorienting a young man. They rendered me mute. Beneath its rich bark, my nostrils sensed the sap. The dedication of Potomak proves it. ${ }^{10}$

Cocteau proceeds to distance himself from those who have embraced the Ballets russes for the wrong reasons-for the "quagmire of charms" which characterized its early repertoire, like Shéhérazade and his own Le Dieu bleu. Cocteau's epiphany is due specifically to the spirit of renunciation which he saw as being at the essence of Le Sacre:

The Russian troupe taught me to spurn everything that stirred in the air. This phoenix teaches that one must burn quickly to be reborn. Its circus games return to the catacombs. There are times when it is brave to dedicate oneself to a cult which is still suspect when other cults offer you a comfortable exploitation. From this richly coloured chrysalis Stravinsky came into the world. ${ }^{11}$

Forty-five years later Cocteau was still preaching

rebellion is indispensable in art, ... the creator always rebels against something, if only instinctively -in other words, the spirit of creation is the highest form of the spirit of contradiction. ${ }^{12}$

9 Cited in Cocteau, Cocteau's World, 88.

10 “' $\dot{A}$ dix-neuf ans, les uns me fêtèrent par sottise ... Je devins ridicule, gaspilleur, bavard, prenant mon bavardage et mon gaspillage pour de l'éloquence et pour de la prodigalité. Ici se placent les spectacles russes. - Ces grandes fêtes pouvaient perdre un jeune homme. Elles servirent ma mue. Derrière une écorce trop riche, mes narines goûtaient la sève. La dédicace du Potomak le prouve." Cocteau, Le Potomak, 8.

11 'La troupe russe m'apprit à mépriser tout ce qu'elle remuait en l'air. Ce phénix enseigne qu'il faut se brûler vif pour renaitre; ces jeux du cirque rejoignent les catacombes. Il y a des circonstances où il est brave de se vouer à un culte encore suspect alors que d'autres cultes vous offrent une exploitation de tout repos. De cette chrysalide chamarrée vint au monde Stravinsky." Cocteau, Le Potomak, 9-10.

12Cited in Steegmuller, Cocteau, A Biography, 87. 
One of the more problematic dimensions of Le Potomak was its relationship to the dream. At the very moment that French literature was signaling the reveille from the dream world of symbolism, Cocteau claimed he, as an artist, fell asleep. His previous works had been composed while he was awake, a near fatal condition for the artist. Presumably "awake" means awake to the dictates of bourgeois fashion, and to the kind of self-consciousness it instilled in him. Cocteau linked the idea of dream-composition with the Stravinsky-double in the text, Canche, who pronounced, "An idea is born from a phrase just as a dream varies according to the changing poses of the dreamer who turns over." 13 There is an oddly Stravinskyan ring to the statement who claimed that the initial impulse for Le Sacre came to him in a dream and who kept a notebook at his bedside to transcribe the previous night's unbidden ideas before they evanesced in daylight. Although Stravinsky was in many ways the antithesis of the creator-dreamer, he frequently acknowledged a dream inception for many of his pivotal works, notably Le Sacre and the Octet for Winds.

Cocteau's new status as a somnambulant visionary is a sub-text through Le Potomak and its numerous appendages. Cocteau speaks of the fevered state in which he finds himself, a state in which he came to realize that the poet and the idiot were separated from one another only by a reversal of syntax. Coming to a profound realization of the irreality of his former reality and the reality of irreality, Cocteau contemplated a metaphor for his existence-and an alternative title for this book-The Sleepwalking Acrobat.

But it is another of his alternate titles which draws our attention most vividly. In the same confession, Cocteau admits he was tempted to rename Le Potomak: Blind Architecture. This touches on what is perhaps the most prescient of Cocteau's obscurely articulated ideas in Le Potomak : "secret architecture."

I didn't know why I created the Eugènes, the Potomak, the butterfly, or what relationship could in fact be established between them. Secret architecture. "What are you preparing?" Canche asked me. I blushed. Impossible to answer him. ${ }^{14}$

It was impossible for Cocteau to understand what gave Le Sacre its monumental force and yet he intuited that it had to be something more than the sheer barbarity of the imagery it evoked. Cocteau guessed that in Stravinsky (as in Gertrude Stein, his shadowy, other model in Le Potomak ${ }^{15}$ ) there was a secret architecture at work. A new syntax is at work in Potomak, a syntax of non-linearity and apparent discontinuity. Le Potomak is the result of automatic writing performed under the stupor induced by Le Sacre.

In his moments of reflection on what resulted in Le Potomak Cocteau was able to identify a few points with clarity. The first, and this would become a veritable mantra in his manifesto writing around Satie and Les Six, was a

13Cited in Cocteau, Cocteau's World, 86.

14 "Les Eugènes, le Potomak, le papillon, je n'ai pas su pourquoi je les créais, ni quel rapport pouvait au juste s'établir entre eux. Architecture secrète. "Que préparez-vous?" me demanda Canche. Je rougis. Impossible de lui répondre." Cocteau, Le Potomak, 53.

15See Steegmuller, Cocteau, A Biography, 92-93. 
cult for simplicity. In the same section in which he pays tribute to the "American woman"-Gertrude Stein-for her directness of expression, Cocteau announces his new preference for the aesthetic of minimalism. He announces a new-found taste for essences of things and a desire to attain them in the simplest possible means. He writes "A plumb line is my preferred mode of transport." 16

Concomitant with a taste for direct expression comes a distaste for anecdote. Pure form is attainable when anecdote is no longer there to obstruct. $\mathrm{He}$ epitomizes this purity in his contemplation of a crystal paperweight:

This arm chair with its stylish motifs and its well chosen velvet, constrains the free eye. I decide to break away from it. A crystal paperweight becomes my art and my comfort. I amazed myself to have preferred it to the fabrics, the furniture, or the oriental vases which hide dust and self-satisfaction. To me it was no longer crystal ... a cube ... six-sided ... a paperweight ... no. Rather it was a carrefour of infinities, a carrousel of silences. Like those who put a conch shell to their ears to hear the ocean, I brought this cube to my eye and there I thought to discover God. ${ }^{17}$

But simplicity and purity (sans anecdote) take forms in Le Potomak that are admittedly incoherent with the awakened state and Cocteau freely allows that this syntax of incoherence is essential to his secret architecture. His writing assumes the coherence of the Turkish alphabet or a vocabulary made entirely of solfège syllables which somehow, inexplicably, carries the reassuring presence of the author to the reader. Again Cocteau states his belief that "a literary masterpiece is nothing but a dictionary in disorder." 18 There is, however an order to the disorder - another of his proposed alternate titles for Le Potomak was, after all, The Philosophy of Disorder. The syntax of incoherence is incoherent only on the level of the dismissed anecdote. Its structure-its constructive secret-follows principles which Cocteau was able to articulate, principles of asymmetry, simultaneity and of additive construction.

Cocteau's new preference for the dangerous beauty of asymmetry is evidenced both in the text and in the drawings which populate it. Equilibrium-as he learned from Le Sacre du printemps-no longer necessitates bi-polar symmetry and rational pattern. Equilibrium can be assured by adding the next element alongside, or on top of its precedent. In his drawings, this takes the form of distortions of Escheresque layerings, recalling Cocteau's famous 1913 depiction of Le Sacre du printemps in which the ballet's entire cast surges out of Stravinsky himself in asymmetric, additive, and simultaneous multiplications

16 "Vers une dame des antipodes, le fil à plomb devint ma locomotion favorite." Cocteau, Le Potomak, 8.

17 "Ce fauteuil, son motif de style et son velours choisi entre tous, contraignent un œil libre. Je décidai de rompre. Un presse-papier de cristal me devint l'art et le confort. Je m'étonnais de lui avoir préféré les étoffes, les meubles, les potiches où se cachent la poussière et la satiété. Il n'était plus pour moi du cristal ... un cube ... six faces ... un presse-papier ... non. Mais un carrefour d'infinis, un carrousel de silences. Comme ceux qui appliquent leur oreille contre un coquillage pour y entendre la mer, j'approchais mon œil de ce cube et j'y pensais découvrir Dieu." Ibid., 14.

18 "Le plus grand chef-d'œuvre de la littérature n'est jamais qu'un dictionnaire en désordre." Ibid., 17. 
of itself. By his own admission, Cocteau's new type of equilibrium is precarious. To describe it, he again summons forth one of his preferred metaphors of the coming decade, the acrobat:

I claim an equilibrium for this volume which is the successively momentary equilibrium of the phrase and of the word. In short, the acrobat and beneath him, emptiness. If nothing goes wrong - step by step along the rope to the other wall-it works. But there is always a tight rope over emptiness. The skill consists in walking, as though on eggs, across death. ${ }^{19}$

If Cocteau recognized but did not completely define the new syntax he sought to adopt from Le Sacre du printemps, others around him did. In his famous essay of November 1914 which began the public redemption of Stravinsky's Le Sacre du printemps, Jacques Rivière, post-war editor of $L a$ Nouvelle Revue française, spoke directly about Le Sacre's true originality. Rivière's analysis of the work's virtues is strikingly similar to the trope which Cocteau constructed through dreaming Potomak.

Rivière's insights on Stravinsky's score centred on two principles he discovered there: what he called its spacious quality, and its acrobatic nature. He defined this spacious quality as "a kind of height or aeration; it is filled with daring lacunae, with simplifications, with wide slashes." 20 Rivière judged this characteristic texture of Le Sacre to be symptomatic of a principle of simultaneous discontinuity. Melodic amplitude and simultaneous discontinuity gave the work its spacious quality; and the disquieting, successive discontinuities which abound in the score defined its acrobatic nature. "There would be some affectation in wanting to remain unaware of the unusual and almost strange character of the music. It constantly bursts out in unbelievable, theoretically inaccessible places ... the music appears suddenly and constantly where it truly has no right to break out, unless by a miracle. Nothing stops it; it has a kind of tremendous facility." 21 The salient qualities of Stravinsky's music could be defined in their discontinuities, both simultaneous (in the spacious texture) and successive (in the capricious acrobatics of their unfolding in time). Rivière found these characteristics, together with a profound asymmetry in every dimension of the work, to be the essence of the work's originality. All extraneous references and allusions were excised. Like Cocteau, Rivière did not concern himself with anecdote in Le Sacre. Finding little depiction or description there, he summarized the work's greatest beauty "in its continual directness."22 Rivière's essay, which Cocteau would have to have read while he was completing Le Potomak confirms the validity of Cocteau's new "secret architecture."

19 “Je réclame pour équilibre à ce volume un équilibre successivement momentané de la phrase et du mot. L'acrobate, en somme, et dessous le vide. Si nul trouble-et sous le pied après le pied la corde, vers l'autre paroi- on arrive. Il y a toujours sur le vide une corde raide. L'adresse consiste à marcher, comme sur des œufs, sur la mort." Ibid., 257.

20 Jacques Rivière, The Ideal Reader; Selected Essays, trans. Blanche A. Price (New York: Meridian Books, Inc., 1960), 128. All quotations from this essay are taken from Blanche A. Price's translation.

21 Ibid., 130.

22Ibid., 133. 
The first lesson of Le Sacre du printemps was to incite Cocteau to revolt against his own bourgeois dilettantism: the placid and uncomprehending cultivation of his family environment; the arenas of this first success, the salon society of turn-of-the-century Paris; and even the first phase of exoticism at the Ballets russes. Instantaneously he became the champion of violent contradiction. From that moment forward his motto was: "Ce que le public te reproche, cultive-le; c'est toi." The public was "le beau monde," but also his bourgeois self. He would cultivate both public- and self-reproach in all his subsequent works. As David Bancroft has stated, his passion for scandal grew from "the desire to be modern and new and to be in the avant-garde, so that the public could not degrade his work by being able to accept it." 23

Francis Steegmuller worried that Cocteau failed to realize that the creation of a masterpiece and the desire to astonish have very little to do with each other and that his attempted impersonation of Stravinsky in the wake of Sacre had a great deal more to do with the effect the work had on the public, than with an understanding of its originality. ${ }^{24}$ But even if the precise blueprints of Le Sacre's secret architecture eluded Cocteau, Le Potomak suggests that he understood what its underlying principles were. In that light, Cocteau's declaration that in the end Le Potomak was a prelude to his other works of criticism is truly astonishing in its clairvoyance. Cocteau himself was quick to realize that although Le Potomak might puzzle, it would certainly fall short of astonishing. To that end he had already begun agitating another project into being which, rather than being a mere response to Stravinsky, would be a collaboration with him.

\section{David}

On 22 January 1914 Cocteau managed to get himself invited to a private audition of the first two acts of Stravinsky's work-in-progress, Le Rossignol. Cocteau used that occasion to propose a collaboration: a piece of experimental theatre to be produced by Jacques Copeau's newly founded théatre du VieuxColombier with music by now notorious avant-gardiste Stravinsky and an astonishing scenario by Cocteau himself. Such a collaboration held the prospect of serving a number of purposes. Cocteau, who was regarded with great suspicion by the Copeau's Nouvelle Revue française group, ${ }^{25}$ stood to gain entry to a literary world from which he had been banished as a lightweight.

23 David Bancroft, "Two Pleas for a French, French Music," Music and Letters 48, no. 2 (April, 1967): 115.

24 Steegmuller, Cocteau, A Biography, 87.

25 While Cocteau initially benefitted from some sympathetic attention from André Gide and Henri Ghéon, the majority of the editorial group at the Nouvelle Revue francaise were firmly lined up against him. Jacques Rivière and Jacques Copeau were particularly derisive in their estimation of the prince frivole of the salons, the latter writing to Gide, "There exists in Paris today one personality that represents everything we detest most forcefully-what to us is the most inimical. Cocteau will never be one of us." Only by allying himself with Stravinsky, recently lionized by Rivière, did Cocteau hope to turn the tide of opinion which was set so firmly against him. See, Auguste Anglès, André Gide et le premier groupe de La Nouvelle Revue française, III: Une inquiète maturité, 1913-1914 (Paris: Éditions Gallimard, 1986), 274-76. 
Stravinsky's willingness to entertain an outside commission was an indication of his growing discontent with Diaghilev's dictatorial style. And Copeau and the Nouvelle Revue française group-despite their reservations about Cocteau-saw the potential of a Stravinsky work in their new theatre as a guarantee of success. On 26 January 1914 Stravinsky wrote his publisher, ${ }^{26}$ stating that he had agreed in principle to write a dance suite for Copeau's theatre in collaboration with Cocteau.

Cocteau's original concept of David was collage of disassociated biblical images, evoking a Biblical Le Sacre du printemps. In letters to Stravinsky he waxed exclamatory over material he had gathered from a lady theosophist:

... one of David's dances ... it is prodigious. He danced before the Sacred Ark: The Dance of the Planets!!!! Imagine the music!!!!!!!!!!! What an exalted thing we could create, forceful and rugged, as in the era when Jehovah was the ogre or when the church sacrificed 2,000 lambs just to please the Good Shepherd. ${ }^{27}$

The incomplete David notebooks ${ }^{28}$ elaborate these images in a text of epigrammes barked from the entrance of a circus sideshow. But the shape of the work took a radical turn once Cocteau arrived in Switzerland on 7 March 1914 where he would spend three weeks in the company of Stravinsky revising, and indeed, completely re-orienting the book. A scenario draft ${ }^{29}$ gives a seminarrative shape to the piece within the same ensemble of images, but prefaces the scenario with significant assumptions in which the voice of Stravinsky can be detected, most notably its opening statement: "Notre danse, elle n'exprime aucune chose." [Our dance expresses absolutely nothing.] From Cocteau's arrival in Switzerland the evolution of the project is documented in his almost daily correspondence with his mother, André Gide and others, plus a solitary and remarkable letter to Misia Sert.

On the day of his arrival he wrote: “... Stravinsky enthusiastic. We're projecting wonderful things on the melting snow." ${ }^{30}$ But only five days later he wrote: "Igor's concept for David excites me. I'm starting the poem over again...." 31 On 17 March his exuberance leaps off the page:

26Letter in the Paul Sacher Stiftung ("Copies des lettres") from Igor Stravinsky, dated Clarens, 26 January 1914 to Nicholas Struve, Russischer Musikverlag, Berlin.

27 “... une des danses de David ... c'est prodigieux. Il a dansé autour de l'arche sainte : La Danse des Planètes!!!! tu imagines la musique!!!!!!!!!!!! quelle chose exaltante nous pouvons faire-drue et rugueuse comme cette époque où Jehovah était l'ogre-où l'église immolait deux mille agneaux pour plaire au bon pasteur." Letter in the Paul Sacher Stiftung from Cocteau dated Paris, 22 February 1914 to Stravinsky in Clarens.

28 A set of four cloth bound notebooks containing a developed, but incomplete text and several pen-and-ink drawings, are held in the collection of the Harry Ransom Humanities Research Centre at the University of Texas at Austin.

29This "brouillon du livret" is held in the Fonds Jean Cocteau, Milly-la-Forêt and has been published in Jean Cocteau, Lettres à sa mère, tome I: 1898-1918, ed. Pierre Caizergues and Pierre Chanel (Paris: Gallimard, 1989), 477-79.

30 “... Stravinsky enthousiaste. Projetons de belles choses sur une neige fondante." Cocteau, Lettres à sa mère, 7 March 1914.

31 "La conception d'Igor pour David m'enthousiasme. Je recommence le poème ..." Cocteau, Lettres à sa mère, 12 March 1914. 
Exhilarating day! Stravinsky played something of the future David. Words cannot express how beautiful it is ... My letters are short for two reasons. The first is sleep and the work. The second is our taste for brevity (modern concision). David will be brief. But as Igor says, it will be a drop that will poison an elephant of five acts. ${ }^{32}$

And again two days later:

... David will be incredible. But what work! (Lucky it's short-the whole will last only twelve minutes) ... No point in telling you that nothing of my original text for David remains. ${ }^{33}$

On the lines and between them, these letters document a transformation in David, from a complicated quasi-biblical melodrama to a ultra-modern miniature. But it is only in the letter to Misia Sert that we learn what precisely the new David would be:

Dear Misia, We must beg you a very important favor. David is taking shape and it excites us more and more. Or rather the principle of David itself: its brevity, its orchestra, its plasticity, its spareness all assign to it a very tiny stage ... Dear Misia, you will love David-indeed you will adore it-and you will help David because of your affection for us both. We beg you to make Serge understand that this has nothing to do with his season (the absolute truth); that David is a miniature without theatrical allure-a parade....

P.S. The three dances, their presentation and the three texts are pure music hall, three acrobatic acts. ${ }^{34}$

Here the nature of the work is spelled out with a precision greater than in any of the preceding references: the three dances which do not constitute a ballet, but an act by itinerant acrobats. This description is repeated and amplified in the postscript where Cocteau restates that the three tours of David are three acrobatic acts drawn from the world of music-hall.

In addition to this description of the context of David, Cocteau elaborates its principles: brevity, its orchestra, its plasticity, and its "dépouillement." All four are worthy of consideration in light of Stravinsky's post-war conversion

32"Journée exaltante. Stravinski a joué quelque chose du David futur. Rien ne peut dire combien c'était beau ... Mes lettres sont courtes pour deux raisons. La première c'est le sommeil et le travail. La seconde c'est notre goût du bref (condensation moderne). David sera bref(vingt minutes) mais c'est comme s'exprime Igor une goutte à empoisonner un éléphant de cinq actes." Cocteau, Lettres à sa mère, 17 March 1914.

33“... David sera prodigieux. Mais quel travail! (Bien que bref-l'ensemble durera douze minutes) ... Inutile de te dire pour David que rien ne reste de mon texte primitif." Cocteau, Lettres à sa mère, 19 March 1914.

34 "Chère Misia, Nous allons encore vous demander un grand et grave service. David se forme et nous passionne de plus en plus. Or le principe même de David, sa brièveté, son orchestre, sa plastique, son dépouillement lui assignent une toute petite scène ... Chère Misia, vous aimerez, vous adorerez David et vous servirez David à cause de votre tendresse pour nous deux. Nous vous supplions de faire, dès utile, comprendre à Serge que cela n'a rien à voir avec la saison (ce qui est la pure vérité) que c'est une courte chose sans attrait théâtral, une parade ... P.-S. Les trois danses, leur présentation et les trois poèmes c'est du music-hall, trois numéros d'acrobates." Letter from Jean Cocteau and Igor Stravinsky to Misia Sert; undated, but attributable to late March 1914, in Cocteau, Lettres à sa mère, t. 1, 476-77. 
to neo-classicism. The progressive brevity of the work has been revealed in Cocteau's letters to his mother. David will not merely be short, it will be short on principle. The principle of brevity was fundamental to Stravinsky's conception of the work as evidenced by Cocteau's returning to it time and again. And it is easy to verify that brevity was one of Stravinsky's objectives in the completed works which surround the time of David: Les Trois Lyriques japonaises, Trois Pièces pour quatuor à cordes, Pribaoutki, Berceuses du chat, and Trois pièces faciles, all multi-movement pieces with total durations of under five minutes. ${ }^{35}$ Brevity had not, to this point, been an important element in Cocteau's aesthetic vocabulary. Cocteau's own writing style subsequent to the war years became increasingly telegraphic.

Cocteau does not state what David's orchestra would be, but he makes it clear that to Stravinsky the instrumental concept was a critical element in the work's identity. By joining the implications of the post-script to the singling out of the orchestra in the definition of the principles of the work, we can hypothesize that the stripped down and transparent ensemble of the music-hall was probably what Stravinsky sought in this work. A few solo winds and brass, together with single strings and piano in the rhythm section translated "brevity" and simplicity into the instrumental concept of the work. Stravinsky would finally achieve this objective a few years later in L'Histoire du soldat.

Finally, David's dépouillement anticipates an important buzzword of the post-war neo-classical polemics. The stripping away of any and all excess became a battle cry of the neo-classicists, Stravinskyan or otherwise. The term was used metaphorically as an antidote to romantic excess or impressionistic brouillard. But it also came to signify certain stylistic traits of neo-classicism, from its stripped-down instrumental ensembles to its bare-bones and nondevelopmental, abstract forms. Cocteau would use the word liberally in his 1919 manifesto on French musical neo-classicism Le Coq et l'Arlequin. Stravinsky would certainly manifest its spirit in the works he wrote from 1914 onward.

Thus, though widely believed to be a phantom work in Stravinsky's œuvre, David seems nevertheless to have left a considerable legacy both in the aesthetic tremors that would follow the end of the first World War, and in the work of Stravinsky himself. Cocteau's correspondence establishes that the collaboration occurred and that Stravinsky exerted a considerable influence on the nature of the proposal, so much so that Cocteau claims twice to have begun over from scratch in the midst of his work. We have a clear idea of what the work would be: a trilogy of music-hall turns done by acrobats in which brevity, plasticity, and renunciation would be supreme. But what would happen on the tiny stage was to be considered no more central to the work than what happened in the "pit" where a stripped down, transparent orchestra would play Stra-

35 Brevity was also imposed by the commission fee. Stravinsky's post-Sacre celebrity encouraged him to demand a hefty commission for the work. In a letter of 15 February 1914 to Cocteau, Stravinsky indicated he would require an advance of 6,000 francs to begin the work (in the Paul Sacher Stiftung ["Copies des lettres", no. 31]). Coctellian histrionics ensued in which assurance of the extreme brevity of the score required persuaded Stravinsky to continue the collaboration. 
vinsky's singularly brief music. Some of that music existed if Cocteau's ecstatic letter of 17 March 1914 is to be believed. And the music which most closely corresponds to the descriptions and aesthetic musings of Cocteau is found on the first two pages of Stravinsky's "Blue Sketchbook" containing materials that can all be dated to 1914 .

The first two pages of that sketchbook contain the motivic and generative material that would eventually find its way into the second of the Trois Pièces pour quatuor à cordes, a work which Stravinsky rapidly assembled to a short-deadlined quasi-commission in July 1914. The most remarkable feature of these two pages is that they are not scored for string quartet, but rather provide detailed instrumentation notes for a music-hall pit band, reminiscent of Cocteau's description of the David orchestra.

The few researchers who have had access to this draft, have assumed it to date from late June of 1914, the date at which Stravinsky received the commission for the string quartet pieces. The fact that the draft is scored for cornet, bassoon, piano and string trio seems to have rung astonishingly few bells for Stravinsky's principal commentator, Robert Craft. Another reminiscence-not to David - but to a real music-hall performer has been used to date this material. In his 1961 dialogue memoirs with Robert Craft, Stravinsky revealed the source for the second string quartet piece to have been the music-hall routine of an enormously popular acrobatic clown called Little Tich.

I had been fascinated by the movements of Little Tich whom I had seen in London in 1914, and the jerky, spastic movement, the ups and downs, the rhythm - even the mood or joke of the music - which I later called Eccentric, was suggested by the art of this great clown ... ${ }^{36}$

Little Tich's "jerky, spastic movement" may well have suggested certain compositional parameters in the second of Trois Pièces, but it is even more likely that Tich had first served as the model for another music hall acrobat, David. Tich's routine can be seen to have suggested compositional and choreographic parameters for David. Its reflection is evident in the referential materials like the little cornet tune which was the first notated idea for the piece. Perhaps more significantly, Tich's jerky, spastic movements can be seen to have suggested the abrupt juxtapositions, the unexpected perforations of rhythmic line, and the asymmetric periodicity of the movement's arch form.

The stumbling block to a straight line connection between Stravinsky's interest in Little Tich and the David project has been Stravinsky's recollection that he saw Tich in 1914. By the time of the composer's 1914 London visit for the premiere of Le Rossignol the David collaboration was over. Under pressure from Diaghilev, Stravinsky had abandoned the project. And without Stravinsky, there was no project for Cocteau to pursue. But on closer examination of the evidence, the likelihood emerges that Stravinsky mis-remembered when he had seen Tich. His 1914 London visit was by far the briefest of the three he

36 Igor Stravinsky and Robert Craft, Memories and Commentaries (London: Faber and Faber, 1981), 95-96. 
had made to date. Five days at the maximum, the London stay is extremely well documented in the composer's scrapbooks and elsewhere. In addition to rehearsals for Le Rossignol, the composer went to a music-hall program that did not include Little Tich; he attended a performance of Strauss' Legend of Joseph; and he spent a good deal of time in bacchic pursuits with his friend Arthur Rubinstein. None of the performances he attended featured Little Tich, not surprisingly since Tich appears not to have been performing in London at that time. A much more likely time for Stravinsky to have seen Tich was in the extended visit of January/February 1913 when Stravinsky spent three to four weeks in London during the Ballets russes season. During this period Tich was the headline attraction at the London Palladium.

Further evidence for Little Tich/David equation is provided by the program notes which were widely distributed during the first four or five years of performances of the string quartet pieces. Written by Stravinsky's then official mouthpiece, the conductor Ernest Ansermet, and recommended by Stravinsky to prospective performers of the work, these notes detail an anecdote for each of the three pieces. The program for the second piece bears a strong similarity to David's music hall turn.

The second is an unhappy juggler who is distraught with a grief that he must hide, while he does his little feats before the watching crowd. One hears in certain glinting tones the flash of his tricks, and as a piercing contrast the sorrow that tortures him while he is at his seeming play. ${ }^{37}$

The Pierrot, or unhappy juggler, here described corresponds well to Cocteau's final version of the David figure. Biblical heroics were long forgotten. What remained was the David described in the letter to Misia Sert: "a parade ... three dances ... pure music-hall ... three turns by acrobats." The David that remained was, as Cocteau later admitted, the first sketch for the ballet scenario he managed to mount in 1917 in collaboration not with Stravinsky, but with the circus clown of French music, Erik Satie. That ballet was called Parade.

The fifty-two measure continuity draft of materials that eventually found their way into the second of Stravinsky's Quartet pieces is very likely a form of the music for the "future David" that Cocteau recorded hearing on 17 March 1914. ${ }^{38}$ The evolution of Cocteau's biblical hero David into a music-hall performer modeled on Stravinsky's vivid impressions of Little Tich is chronicled between the lines of Cocteau's correspondence. Stravinsky's own identification of that music is corroborated, if obliquely, between the image passed from program note to retrospective memoir despite the muddled chronology.

37Ernest Ansermet, "Strawinsky's First Quartet," trans. F. H. M[artens]. Program booklet to the performance of the London Philharmonia Quartet, 13 February 1919 [no p.].

38 There is also a strong case to be made here for the first of the Trois Pièces for which a piano, 4-hands manuscript exists in the Ansermet estate, dated April 1914. Arguably the earliest of Stravinsky's Pièces faciles for piano, 3-hands, this version has a prima part that even Cocteau might have been able to play. The whirling circularity of the simple tune interrupted by an unpredictably placed "ostinato" on visit from a different tonal planet, would certainly have made an appropriate match for Cocteau's surreal music-hall piece. 
What then are the ideas that Little Tich's "jerky, spastic movement, the ups and downs and the rhythm" suggested for the David score? As identified on my copy of the draft, they constitute a repertory of abstract fragments common to Stravinsky's style; a brittle polychord (example 1a) and two other interruptive fragments (examples $1 \mathrm{~b}$ and $1 \mathrm{c}$ ); a burlesque ostinato typecast in the bassoon (example 1d); two citations of acrobatic music clichés (examples le and $1 \mathrm{f}$ ) and two motivic patterns in interlocking thirds (examples $1 \mathrm{~g}$ and $1 \mathrm{~h}$ ).

Despite the haphazard appearance of the two-page continuity draft that ensues, the composer has clearly cued an order of succession for several of the ideas. The effect of the indicated juxtapositions is certainly jerky and spastic. The most interesting ideas are truncated before they have barely begun. The most mundane ideas-the cornet tune (example 1e) and the scherzando (example 1f)-are repeated beyond their worth. The rhythm of the form is chaotic-nonsensical. It offers an incongruity that approaches the comic.

And yet this incongruity is entirely superficial. It masks the fact that most of the ideas on the page grow out of the same generating cell. Despite appearances, this hodgepodge of ideas is anchored on a single polarity embedded in the polychord itself (example 1a): a simultaneity of D major / E-flat minor triads, joined at the third (F-sharp $=$ G-flat). All accompanimental (the F-sharp / B-flat bassoon ostinato in example 1d) and interruptive materials (examples $1 \mathrm{~b}$ and $1 \mathrm{c}$ ) are subsets. The tritone-prescribed ambitus of the two principal motivic ideas (examples $1 \mathrm{~g}$ and $\mathrm{lh}$ ), themselves studies in interlocking thirds, are also drawn from this same generative unit. What does this ballet fragment reveal about the composer of Petrushka and Le Sacre du printemps? First, it is clear that the David draft will not upset anyone's hierarchy of favorite Stravinsky ballets. In the form the composer abandoned it, it is little more than a collection of ideas referential to the world of music-hall. But the nature of reference and its potential for transformation offer important clues on Stravinsky's imminent conversion to neo-classicism.

Stravinsky himself - though he was usually loath to propagate labels the critics had thrust upon him - admitted that the David material was arguably his first venture into neo-classicism:

In spite of the obvious recollection of Petroushka, it seems to me these Three Pieces look ahead to the Pièces Faciles for piano duet of one year later, and from the Pièces Faciles to my so aberrant "neo-classicism" (in which category, nevertheless, and without knowing it was that, I have managed to compose some not unpleasing music). ${ }^{39}$

The incipient, if aberrant, neo-classicism of David rests in the qualities which Stravinsky himself imposed on the collaboration with Cocteau: a brittle and unblended instrumental sound, brevity, plasticity, and simplicity. Stravinsky achieved these ideals in his tiny draft score by liberal, if somewhat distorted, reference to a clichéd musical language drawn from the world of the circus and 
1a

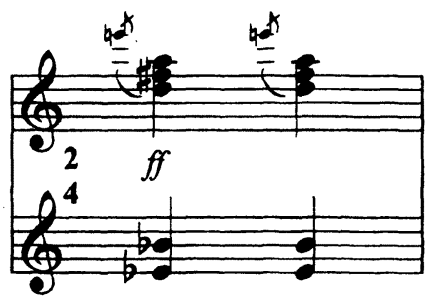

1b

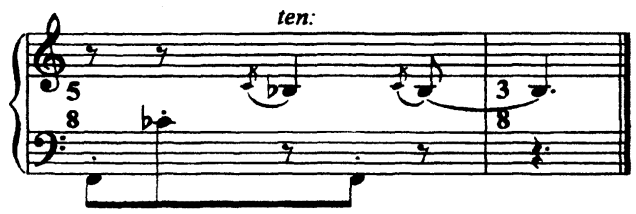

$1 c$

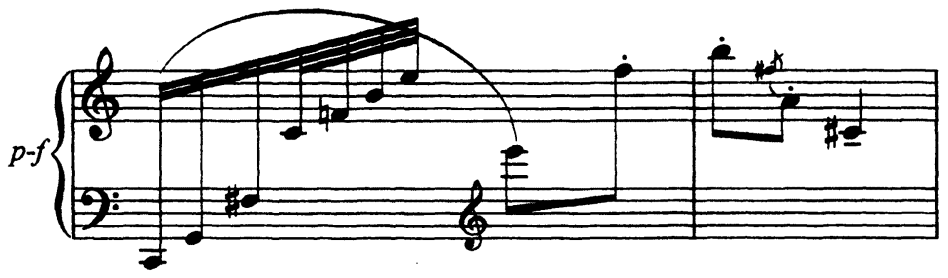

1d

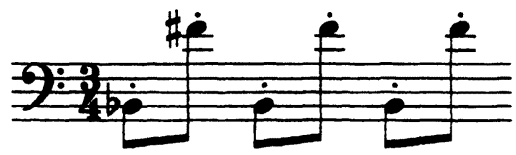

1e

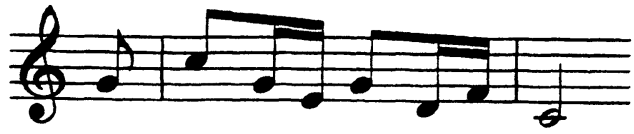

1f

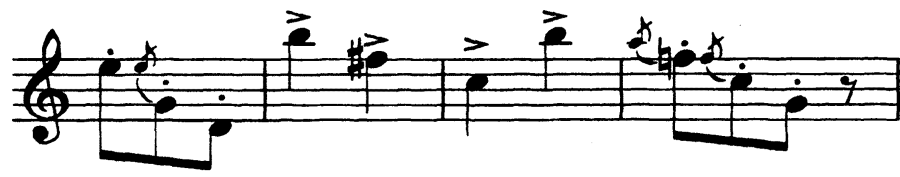

19

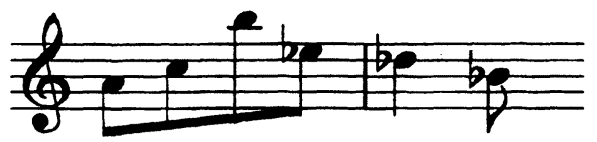

1h

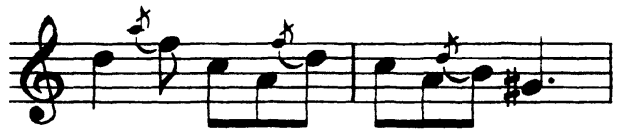

Example 1 (a-h). Harmonic and motivic materials for David / Trois Pièces pour quatuor à cordes, Blue sketchbook, $1^{\mathrm{T}} / 3^{\mathrm{r}}$, Paul Sacher Stiftung, Basel 
music-hall. Stock snippets of circus band doggerel are forged into a collage-a jerky patchwork form. But David is not an artful re-take on popular entertainment music of the first decade of the century. Stravinsky's references to music-hall are only that: references. These references bring with them the truth of simplicity. But in his application Stravinsky abstracts them from their simplistic context. They become almost neutral objects from which he constructs a form of calculated balance and proportion. The earlier cited analogy to Picasso is again germane. If Petrushka summoned the same pathos as Picasso's saltimbanque, David and its legacies in L'Histoire du soldat and beyond abstracts from its model in the same ways as Picasso's war-time cubism. The potent truth of simple image is what is retained. With it the artist fashions a new construction.

As Stravinsky's first foray into neo-classicism there is an apparent contradiction in the fact that the composer ascribed programs (i.e., narrative metaphors) for the David-turned string quartet pieces. But in the Stravinsky-sanctioned explanation Ansermet concludes with a noble ascription: “... this music is absolute music in the true sense of the word, that is to say, music innocent of any and all suspicion of a literary or philosophic program." 40

The adoption of the plastic rhythms of an acrobatic clown provided Stravinsky with the first opportunity to forge a work on an invisible program, one which offered a means of generating a musical structure rather than imposing an anecdote on the music. This provided for a genuinely abstract musicabstracted from its objective source-and yet capable of furnishing material from which and on which the music could build its own coherent structure. It is arguably the beginning of neo-classicism.

And for Cocteau? His best first shot at public astonishment, David, failed to see the light of day. If his efforts to astonish by imitation and transposition in Le Potomak resulted in more belated bewilderment than astonishment, his efforts to astonish by association were scuttled entirely by the backstage betrayals at the Ballets russes and La Nouvelle Revue française. But just as David's legacy in the work of Stravinsky gestated invisibly across the series of works from the Trois Pièces pour quatuor à cordes to L'Histoire du soldat, the seeds sewn in Cocteau's collaboration with Stravinsky on the David project germinated in other surprising forms. The lineage from David to Parade has been widely acknowledged, but no less significant are the David-based roots of Cocteau's aesthetic manifesto of the avant-garde, Le Coq et l'Arlequin, whose principles of brevity, plasticity, and dépouillement can all be traced to Cocteau's astonishing encounter with Stravinsky.

\section{Abstract}

Cocteau always dated his epiphany in the avant-garde to the shock of Stravinsky's revolutionary Le Sacre du Printemps. Diaghilev famously enjoined Cocteau in 1913: "Étonne-moi!" The most tantalizing of Cocteau's efforts to

40 Ansermet, "Strawinsky's First Quartet" [no p.]. 
astonish was his proposed 1914 collaboration with Stravinsky, the ballet David, a work previously thought to have left few traces. But even before, Cocteau had embarked on the "molting" which he later credited as his true birth as an artist. Classed by its author as a novel, Le Potomak is part graphic fable, part somnambulant stream-of-consciousness, part compendium of inflammatory aphorisms or, as Cocteau himself declared, a "fever chart"-an aftershock reverie indebted to the composer of Le Sacre. This paper evaluates Le Potomak in the narrative of Cocteau's "astonishment" as an index of the understanding of the musical avant-garde in France during the first decades of the twentieth century.

\section{Résumé}

Cocteau était convaincu que son épiphanie dans l'avant-garde datait du choc produit par l'œuvre révolutionnaire de Stravinsky, Le Sacre du printemps. En 1913, Diaghilev avait enjoint Cocteau de le surprendre par cette formule célèbre : "Étonne-moi! " Parmi les efforts que Cocteau a fournis dans le dessein d'étonner, le plus excitant est sa collaboration projetée avec Stravinsky en 1914, le ballet David, une œuvre que l'on avait d'abord jugée sans conséquence. Même auparavant, Cocteau avait commencé une « mue » qu'il a plus tard définie comme sa vraie naissance en tant qu'artiste. Le Potomak, qualifié de roman par son auteur, est en partie une fable imagée, un flot d'idées somnambuliques, un condensé d'aphorismes incendiaires ou, selon Cocteau lui-même, une " courbe de température »-une rêverie par émulation envers le compositeur du Sacre. Cet essai évalue Le Potomak par la narration de l'« étonnement " de Cocteau en tant qu'indice de compréhension de l'avantgarde musicale en France pendant les premières décennies du $\mathrm{XX}^{\mathrm{e}}$ siècle. 